ANDRADE JÚNIOR, VC; OLIVEIRA, AJM; GUIMARÃES, AG; FERREIRA, MAM; CAVALCANTI, VP; FERNANDES, JSC. 2020. Repeatability and heritability of production characters in strawberry fruits. Horticultura Brasileira 38: 89-93. DOI - http://dx.doi.org/10.1590/S0102-053620200114

\title{
Repeatability and heritability of production characters in strawberry fruits
}

\author{
Valter C Andrade Júnior ${ }^{1} \mathbb{D}$; Altino JM Oliveira ${ }^{1} \mathbb{D}$; Amanda G Guimarães ${ }^{2} \mathbb{D}$; Marcos Aurélio M Ferreira ${ }^{2} \mathbb{D}$; \\ Vytória P Cavalcanti ${ }^{1} \mathbb{D}$; José Sebastião C Fernandes ${ }^{2 \mathbb{D}}$
}

${ }^{1}$ Universidade Federal de Lavras (UFLA), Lavras-MG, Brasil; valter.andrade@ufla.br; altinojrmendes@gmail.com; vytoriapc@yahoo. com.br; ${ }^{2}$ Universidade Federal dos Vales do Jequitinhonha e Mucuri (UFVJM), Diamantina-MG, Brasil; marcosmamf23@yahoo.com.br; marcaumife2010@hotmail.com; jscf1912@gmail.com

\begin{abstract}
The estimation of repeatability coefficient provides support to define the number and the appropriate period of genotype evaluations, obtaining better success in breeding programs, in order to lower labor costs. Therefore, knowing repeatability and heritability parameters is relevant. Thus, the aim of this study was to estimate the repeatability and heritability coefficients and accurately determine the number of measurements. Eight strawberry cultivars were analyzed in a randomized block design with four replicates and eighteen plants per plot, being harvested twice a week over a period of six months (May to October, 2012), totalizing six evaluations. Among the evaluated traits, the estimated heritabilities ranged from $3.13 \%$ (number of fruits) to $40.20 \%$ (average fruit mass) whereas the repeatability ranged from 9.00 to $42.06 \%$ for the same characters. The minimum number of evaluations, to reach a coefficient of determination with an accuracy of about $80 \%$, ranged from the maximum of 40 for fruit number and the minimum of 6 for average fruit mass. In order to be considered commercially important marketable fruit mass, minimum of 20 evaluations are required, it means, at least, 20 months.
\end{abstract}

Keywords: Fragaria $x$ ananassa, genetic breeding, number of measurements.

\begin{abstract}
RESUMO
Repetibilidade e herdabilidade de caracteres de produção nos frutos do morangueiro

A estimativa do coeficiente de repetibilidade possibilita auxiliar na definição do número e no período adequado de avaliações dos genótipos obtendo melhor êxito em programas de melhoramento, afim de ocasionar menor custos de mão-de-obra. Dessa forma, é relevante o conhecimento de parâmetros de repetibilidade e herdabilidade. Assim, o objetivo do trabalho foi estimar o coeficiente de repetibilidade e herdabilidade e determinar o número de medições com a precisão desejada. Para isso, oito cultivares de morangueiro foram analisadas em delineamento em blocos casualizados com quatro repetições e dezoito plantas por parcela, sendo a colheita realizada duas vezes por semana em um período de seis meses (maio a outubro de 2012), considerando então seis avaliações. Entre os caracteres analisados, as herdabilidades estimadas variaram de 3,13\% (número de frutos) a $40,20 \%$ (massa média de frutos) ao passo que as repetibilidades variaram entre 9,00 e $42,06 \%$, para os mesmos caracteres. O número mínimo de avaliações para se atingir um coeficiente de determinação com $80 \%$ precisão variou entre o máximo de 40 para o caráter número de frutos e o mínimo de 6 para o caráter massa média de frutos. Para o caráter considerado mais importante do ponto de vista comercial (massa comercial de frutos) há necessidade de pelo menos 20 avaliações para se atingir a referida determinação, ou seja, pelo menos um ano e oito meses.
\end{abstract}

Palavras chave: Fragaria $x$ ananassa, melhoramento genético, número de medições.

Received on May 7, 2019; accepted on November 22, 2019

$S^{t}$ rawberry crop (Fragaria $\mathrm{x}$ ananassa) is very appreciated by consumers since its sensory and nutritional characteristics are very well defined (Guimarães et al., 2016), it is also a highly valued crop for in natura commercialization as well as for industrial processing (Guimarães et al., 2014). The cultivation demands skilled labor from cultural practices up to harvest which are performed more than once a week during fruit ripening (Henz, 2010; Ronque et al., 2013).
In order to overcome the barriers to the selection of the most productive cultivars with good-fruit quality (Guimarães et al., 2015; Mishra et al., 2015), attaining information on the number of harvests which are necessary to obtain superior cultivars in shorter time, lowest costs of labor and resources is essential (Azevedo et al., 2016).

Thus, using statistical procedures, it is possible to evaluate production characteristics of each harvest in order to predict how many accurate observations should be made on each character, to confirm data authenticity, achieving high productivity and avoiding production costs. Repeatability coefficient is used as statistics parameter (Cargnin, 2016); it is defined as the correlation between measurements of a given character in the same individual, whose measurements were repeated in time or space (Cruz et al., 2012). Additionally, repeatability expresses the maximum limit that in a broad sense can be achieved, being heritability the explanation of the 
proportion of phenotypic variance which is attributed to genetic differences confused with the environmental effects on the cultivar (Cruz et al., 2012).

Repeatability coefficient has been estimated for many species, mainly the perennial ones such as grape (Sales et al., 2019) and semi- perennial such as sugar cane (Silva et al., 2018). However, this coefficient can also be estimated for annual vegetable species in which several harvests are performed in a same cycle, as kale (Azevedo et al., 2016), tomato (Adewale \& Adebo, 2018), bell pepper (Pimenta et al., 2016) and cucumber (Cardoso, 2006). For strawberry crop, no reports can be found in relation to this parameter, which makes estimation necessary, since several harvests are carried out per cycle in the same plant.

Considering that no information was found on the number of evaluations which are necessary for agronomic characteristics in selective processes on strawberry crop, this study aimed to estimate the repeatability and heritability coefficients and accurately determine the number of measurements for predicting strawberry crop performance.

\section{MATERIAL AND METHODS}

Eight strawberry cultivars were used, considering that six were shortday cultivars (Festival, Camarosa, Campinas, Toyonoka, Dover and Oso Grande) and two neutral-day ones (Aromas and Diamante). The matrices were obtained from Multiplanta Biotecnologia Vegetal Ltda.

\section{Environment and experimental} design

The experiment was carried out at the Farm of Mape Frutas Ltda., located in the municipality Datas-MG $\left(18^{\circ} 26^{\prime} \mathrm{S}\right.$, $43^{\circ} 39^{\prime} \mathrm{W}$, altitude $1,244 \mathrm{~m}$ ). The climate of the region is humid tropical, Aw, according to Köppen classification, with dry winter and rainy summer. The soil was classified as Quartzarenic Neosol.

We used a randomized block design, with eight strawberry cultivars, four replicates and eighteen plants per plot, spaced $0.30 \times 0.30 \mathrm{~m}$, and $2 \mathrm{~m}^{2}$ useful area.

Strawberry seedlings were planted on March 1, 2012 under a low tunnel system, covered with 75 micron thickness plastic, $0.80 \mathrm{~m}$ height from the seedbed surface. Soil was also covered with white plastic, 30 micron (mulching), measuring 0.20 height, 64 $\mathrm{m}$ length and $1 \mathrm{~m}$ width. Fertigation was sprinkler irrigated and cultural practices were carried out according to the recommendations for the crop.

Harvest began 60 days after seedling planting when fruits showed $75 \%$ ripening, being performed twice a week during six months (May-October, 2012), considering six evaluations, totalizing 48 harvests.

\section{Evaluated characteristics}

Fruits were taken to Laboratório de Tecnologia Biomassa do Cerrado, of Universidade Federal dos Vales do Jequitinhonha e Mucuri, at Campus $\mathrm{JK}$, in Diamantina-MG, being counted and weighed. Strawberries with mass superior to 10 grams were classified as suitable to be commercialized in natura (Guimarães et al., 2015). The following characteristics were evaluated: a) average mass of total fruits (MMFT) and average mass of marketable fruits (MMFC), obtained through production per plant and number of fruits ratio, both expressed in $g$ fruit ${ }^{-1} ; b$ ) number of total fruits (NFT) and marketable fruits (NFC) in each harvest, counting per experimental unit and expressed in fruit plant $^{-1}$; c) total productivity (PT) and marketable productivity (PC), counting in each harvest month, fruit production of each plot of each cultivar, expressed in $\mathrm{t} \mathrm{ha}^{-1} ; \mathrm{d}$ ) length (COMP) and diameter (DIAM) of the fruit being measured in longitudinal and transversal directions of the fruit, respectively, using a digital caliper (Digital Caliper 0-15 cm). Three strawberry fruits were evaluated per plot, in each cultivar in each harvest and the results expressed in millimeters $(\mathrm{mm})$.

\section{Statistical analysis}

The analyses were performed using complete repeatability statistical model (Resende, 2006), $\mathrm{Y}_{\mathrm{ijk}}=\mu+\mathrm{g}_{\mathrm{i}}+\mathrm{m}_{\mathrm{j}}+$ $r_{k}+g m_{i j}+g r_{i k}+m_{j k}+g m r_{i j k}$, in which $\mathrm{Y}_{\mathrm{ijk}}=$ observations of $\mathrm{k}$ repetitions of $\mathrm{j}$ harvests of i genotypes; $\mu=$ overall average; $g_{i}=$ effect of $i$ genotypes ( $\mathrm{i}=$ $1,2, \ldots, 8$ individuals); $\mathrm{m}_{\mathrm{j}}=$ effect of measurement $(j=1,2,3,4,5$ and 6$)$; $r_{k}=$ effect of repetition $(k=1,2,3$ and 4$)$; $\mathrm{gm}_{\mathrm{ij}}=$ interaction between genotypes and measurement; $\mathrm{gr}_{\mathrm{ik}}=$ interaction between genotypes and repetition; $\mathrm{mr}_{\mathrm{jk}}=$ interaction between measurement and repetition; $\mathrm{gmr}_{\mathrm{ijk}}=$ triple interaction or random residue between genotype, measurement and repetition. Effects of $\mathrm{gm}_{\mathrm{ij}}$ are permanent environmental effects, from one harvest to another.

Using the expected average squares in variance analysis (Box 1), repeatability coefficient $(\rho)$ (equation 1 ) and heritability $\left(\mathrm{h}^{2}\right)$ (equation 2 ) were estimated:

$$
\rho=\frac{\sigma_{\mathrm{g}}^{2}+\sigma_{\mathrm{gr}}^{2}}{\sigma_{\mathrm{F}}^{2}}, \quad \text { (equation 1) }
$$

In which $\sigma_{g}^{2}=$ the variance among cultivars; $\sigma_{\mathrm{gr}}^{2}=$ genotypic variance and repetition; $\sigma_{\mathrm{rr}}^{2}=$ permanent phenotypic variance among plants, which means, genotypic and permanent environment from one harvest to another.

$$
\mathrm{h}=\left(\mathrm{h}^{2}\right): \mathrm{h}^{2}=\frac{\sigma_{\mathrm{g}}^{2}}{\sigma_{\mathrm{F}}^{2}}, \quad \text { (equation 2) }
$$

In which $\sigma_{\mathrm{g}}^{2}=$ variance among cutivars $\sigma_{\mathrm{F}}^{2}=$ phenotypic variance.

The number of measurements $\left(\eta_{0}\right)$ (equation 3) necessary to predict the real value of individuals, based on appropriate coefficient of determination $\left(\mathrm{R}^{2}\right)$ (minimum of $80 \%$ ), was calculated according to Cruz et al. (2012):

$$
\eta_{0}=\frac{R^{2}(1-p)}{\left(1-R^{2}\right) p} . \quad \text { (equation 3) }
$$

In which $\mathrm{R}^{2}=$ represents the percentage of prediction of actual value of selected individuals, based on $\eta$ obtained by equation (4):

$$
\mathrm{R}^{2}=\frac{\eta \rho}{\rho(n-1)+1} . \quad \text { (equation 4) }
$$

\section{RESULTS AND DISCUSSION}

Analysis of variance revealed significant differences $(\mathrm{P}<0.05)$ for most evaluated variables, except for effect of blocks (Table 1). These results showed variability among the evaluated genotypes, corroborating that the genetic component of variance, confused with permanent environmental effects, is significant (Manfio et al., 2011). 
Average repeatability values were estimated $(0.30<\rho<0.60)$ based on the classification of repeatability coefficients in relation to the magnitude (Resende, 2002). In this study the repeatability coefficients of the eight studied characters showed indexes varying from $\rho=0.09$ (total fruit number) to $\rho=0.42$ (average mass of total fruit) (Table 3).

Values for MMFT (0.42), COMP (0.39) and DIAM (0.34) showed average regularity of character repetition, from one cycle to the other, considering being satisfactory values. Repeatability values for other characteristics were low $(\rho \leq 0.30)$ MMFC (0.16), PT (0.16), PC (0.22), NFT (0.08) and NFC (0.20), which makes us suggest more number of evaluations for more accurate results (Table 2).

Box 1. Analysis of variance of strawberry cultivars evaluated from May to October, 2012 from the municipality of Datas-MG (Mape Frutas Ltda. Farm) $(\mathrm{M}=$ measurements; $\mathrm{B}=$ blocks; $\mathrm{G}=$ genotypes; $\mathrm{Q}_{\mathrm{M}}=$ average square of measurements; $\mathrm{Q}_{\mathrm{B}}=$ average square of block; $\mathrm{Q}_{\mathrm{G}}=$ average square of genotypes; $\mathrm{Q}_{\mathrm{MxB}}=$ average square of measurements/blocks; $\mathrm{Q}_{\mathrm{GxM}}=$ average square of genotype $/ \mathrm{Q}_{\mathrm{GxB}}=$ average square of genotypes/blocks; $\mathrm{Q}_{\mathrm{GxMxB}}=$ average square of genotype/blocks). Diamantina, UFVJM, 2017.

\begin{tabular}{|c|c|c|c|}
\hline Variation source & GL & QM & $\mathbf{E}(\mathbf{Q M})$ \\
\hline Measurements & 5 & $\mathrm{Q}_{\mathrm{M}}$ & $\sigma_{\mathrm{gmb}}^{2}+\mathrm{I} \sigma_{\mathrm{mb}}^{2}+\mathrm{K} \sigma_{\mathrm{mb}}^{2}+\mathrm{IK} \sigma_{\mathrm{m}}^{2}$ \\
\hline Blocks & 3 & $\mathrm{Q}_{\mathrm{B}}$ & $\sigma_{\mathrm{gmb}}^{2}+\mathrm{I} \sigma_{\mathrm{mb}}^{2}+\mathrm{J} \sigma_{\mathrm{gb}}^{2}+\mathrm{IJ} \sigma_{\mathrm{b}}^{2}$ \\
\hline Genotypes & 7 & $\mathrm{Q}_{\mathrm{G}}$ & $\sigma_{\mathrm{gmb}}^{2}+\mathrm{K}^{2}{ }_{\mathrm{gm}}+\mathrm{J} \sigma_{\mathrm{gb}}^{2}+\mathrm{JK} \sigma_{\mathrm{g}}^{2}$ \\
\hline $\mathrm{M} \times \mathrm{B}$ & 15 & $\mathrm{Q}_{\mathrm{MxB}}$ & $\sigma_{\mathrm{gmb}}^{2}+\mathrm{I} \sigma_{\mathrm{mb}}^{2}$ \\
\hline $\mathrm{G} \times \mathrm{M}$ & 35 & $\mathrm{Q}_{\mathrm{GxM}}$ & $\sigma_{\mathrm{gmb}}^{2}+\mathrm{K} \sigma_{\mathrm{gm}}^{2}$ \\
\hline G x B & 21 & $\mathrm{Q}_{\mathrm{G} \times \mathrm{B}}$ & $\sigma_{\mathrm{gmb}}^{2}+\mathrm{J} \sigma_{\mathrm{gb}}^{2}$ \\
\hline $\mathrm{G} \times \mathrm{M} \times \mathrm{B}$ & 105 & $\mathrm{Q}_{\mathrm{GxMxB}}$ & $\sigma_{\mathrm{gmb}}^{2}$ \\
\hline
\end{tabular}

characteristics are quite influenced by environmental variations, which should increase the number of measurements suitable to express the accuracy gain of the real value of individuals, or the genetic difference among cultivars, since they were differentiated in photoperiods (short and neutral) which may differentiate in manifestation of its potential.

Oliveira \& Fernandes (2001), estimating repeatability coefficient for characters of açaí bunch, for total weight, fruit weight, number of fruits and fruit yield also showed repeatability coefficient with low magnitudes $(p \leq 0.30)$. The highest repeatability and determination coefficients were obtained for average mass of fruits. These authors determined that average fruit mass can be used as a parameter for selection in less rigorous breeding methods, as repeatability coefficient expresses the maximum broad-sense heritability values. However, the desirable number of measurements for this character should be almost three times the one used by the authors.

Estimated heritability values of this study can be classified as median (15 to $50 \%$ ) or low values (1 to $15 \%$ ) according to Resende (1995). The group considered of median characteristics is represented by MMFT (40.20\%), MMFC (15.82\%), COMP (29.97\%), DIAM (31.10\%) and PC $(18.05 \%)$ and the low group was represented by PT $(7.92 \%)$, NFT $(3.13 \%)$ and NFC (13.56\%) (Table 3 ). These reduced heritability values are related to the fact that most of the

Table 1. Analysis of variance of production variables and their respective probabilities of significance $\mathrm{P}(\mathrm{F})$ for average total fruit mass (MMFT), average marketable fruit mass (PMFC), length (COMP), diameter (DIAM), total productivity (PT), marketable productivity (PC), number of total fruits (NFT), number of marketable fruits (NFC) of strawberry cultivars (Fragaria x ananassa) analyzed from May to October, 2012 from the municipality of Datas-MG (Farm of Mape Frutas Ltda.). $(\mathrm{M}=$ measurements; $\mathrm{R}=$ repetition; $\mathrm{B}=\mathrm{blocks}$; $\mathrm{G}=$ genotypes). Diamantina, UFVJM, 2017.

\begin{tabular}{lccccccccc}
\hline Variation source & GL & MMFT & MMFC & COMP & DIAM & PT & PC & NFT & NFC \\
\hline Measurements & 5 & 0.000 & 0.003 & 0.000 & 0.000 & 0.000 & 0.000 & 0.001 & 0.000 \\
Block & 3 & 0.254 & 0.980 & 0.272 & 0.717 & 0.049 & 0.018 & 0.088 & 0.034 \\
Genotypes & 7 & 0.000 & 0.000 & 0.000 & 0.000 & 0.000 & 0.000 & 0.000 & 0.000 \\
M x B & 5 & 0.003 & 0.296 & 0.043 & 0.040 & 0.004 & 0.101 & 0.003 & 0.023 \\
G x M & 5 & 0.000 & 0.002 & 0.000 & 0.000 & 0.000 & 0.000 & 0.000 & 0.000 \\
G x B & 21 & 0.106 & 0.365 & 0.000 & 0.010 & 0.000 & 0.001 & 0.000 & 0.000 \\
G x M x B & 105 & & & & & & & & \\
\hline Total & 151 & & & & & & & \\
\hline
\end{tabular}


phenotypic variation observed was influenced by the environment, in other words, controlled by several genes (Lira Júnior et al., 2014). Vieira et al. (2017), studying different strawberry cultivars in Lavras-MG, found heritability values for MMFT (75.66\%) above this study, which shows that, besides being different

Table 2. Estimation of repeatability coefficient $(\rho)$ and estimation of heritability $\left(h^{2}\right)$, number of measurements $(\eta)$ and estimation of determination coefficient $\left(\mathrm{R}^{2}=80 \%\right)$ for average mass of total fruits (MMFT), average mass of marketable fruits (MMFC), length (COMP), diameter (DIAM), total productivity (PT), marketable productivity (PC), number of total fruits (NFT), number of marketable fruits (NFC), of strawberry cultivars (Fragaria $\mathrm{x}$ ananassa), analyzed from May to October, 2012 from the municipality of Datas-MG (Farm of Mape Frutas Ltda.). Diamantina, UFVJM, 2017.

\begin{tabular}{lcccc}
\hline Variables & $\boldsymbol{\rho}$ & \multicolumn{1}{c}{$\mathbf{h}^{\mathbf{2}}$} & $\boldsymbol{\eta}$ & $\mathbf{R}^{\mathbf{2}}$ \\
\hline MMFT & $42.06 \%$ & $40.20 \%$ & $6(5.50)$ & $81.33 \%$ \\
MMFC & $16.87 \%$ & $15.82 \%$ & $20(19.70)$ & $54.90 \%$ \\
COMP & $39.80 \%$ & $29.97 \%$ & $6(6.04)$ & $79.86 \%$ \\
DIAM & $34.85 \%$ & $31.10 \%$ & $7(7.47)$ & $76.24 \%$ \\
PT & $16.03 \%$ & $7.92 \%$ & $21(20.94)$ & $53.40 \%$ \\
PC & $22.89 \%$ & $18.05 \%$ & $13(13.47)$ & $64.04 \%$ \\
NFT & $8.99 \%$ & $3.13 \%$ & $40(40.47)$ & $37.22 \%$ \\
NFC & $20.74 \%$ & $13.56 \%$ & $15(15.28)$ & $61.09 \%$ \\
\hline
\end{tabular}

Table 3. Number of measurements required $(\eta)$ associated with different determination coefficients $\left(\mathrm{R}^{2}\right)$ estimated from May to October, 2012 for average total fruit weight (MMFT), average marketable fruit weight (MMFC), length (COMP), diameter (DIAM), total productivity (PT), marketable productivity (PC), total fruit number (NFT), marketable fruit number (NFC) of strawberry cultivars (Fragaria x ananassa) analyzed from May to October, 2012 from the municipality of Datas-MG (Farm of Mape Frutas Ltda.). Diamantina, UFVJM, 2017.

\begin{tabular}{|c|c|c|c|c|c|}
\hline Variables & $R^{2}(\%)$ & $\eta$ & Variables & $R^{2}(\%)$ & $\eta$ \\
\hline \multirow{5}{*}{ MMFT } & 80 & 5.50 & \multirow{5}{*}{ MMFC } & 80 & 19.70 \\
\hline & 85 & 7.80 & & 85 & 27.92 \\
\hline & 90 & 12.39 & & 90 & 44.34 \\
\hline & 95 & 26.16 & & 95 & 93.61 \\
\hline & 99 & 136.33 & & 99 & 487.80 \\
\hline \multirow{5}{*}{ COMP } & 80 & 6.04 & \multirow{5}{*}{ DIAM } & 80 & 7.47 \\
\hline & 85 & 8.57 & & 85 & 10.59 \\
\hline & 90 & 13.61 & & 90 & 16.82 \\
\hline & 95 & 28.73 & & 95 & 35.51 \\
\hline & 99 & 149.73 & & 99 & 185.03 \\
\hline \multirow{5}{*}{ PT } & 80 & 20.93 & \multirow{5}{*}{$\mathrm{PC}$} & 80 & 13.47 \\
\hline & 85 & 29.66 & & 85 & 19.08 \\
\hline & 90 & 47.11 & & 90 & 30.31 \\
\hline & 95 & 99.45 & & 95 & 63.99 \\
\hline & 99 & 518.21 & & 99 & 333.44 \\
\hline \multirow{5}{*}{ NFT } & 80 & 40.46 & \multirow{5}{*}{ NFC } & 80 & 15.28 \\
\hline & 85 & 57.32 & & 85 & 21.65 \\
\hline & 90 & 91.04 & & 90 & 34.39 \\
\hline & 95 & 192.21 & & 95 & 72.60 \\
\hline & 99 & 1001.53 & & 99 & 378.30 \\
\hline
\end{tabular}

genetic materials, the environment itself interferes in the expression of the characteristics.

Estimated heritabilities showed an interval between $3.13 \%$ (number of total fruits) and $40.20 \%$ (average mass of total fruits) (Table 2), showing that estimates were always lower than the repeatability coefficient, according to Resende (2002), broad-sense heritability is always lower than the repeatability coefficient. Repeatability represents the maximum value that the broadsense heritability can reach (Cruz et al., 2012). Being the difference between repeatability and heritability, due to the fact that the genotypic variance used to estimate repeatability is not only related to genetic origin, since the permanent environmental variance components among individuals are still confused with genotypic variance (Azevedo et al., 2016). Thus, repeatability approaches heritability when variance provided by permanent environmental effects is minimized (Cruz et al., 2012), it means, if the variance estimated was only of genetic nature, repeatability and heritability coefficients would be corresponding (Lopes et al., 2001). As heritability showed low estimate values, the phenotypic value becomes an unreliable measure of genotypic value, whose apparent relative superiority may not be due to the genetic cause. Thus, the increase of number of measurements, minimizing environmental influence or adding greater genetic variability may result in increased accuracy.

The number of measurements performed for one $\mathrm{R}^{2}$ of $80 \%$ accuracy is considered appropriate according to Resende (2002) and Souza Sobrinho et al. (2010). Thus, the number of evaluations performed in this study (six months) was sufficient for two variables: MMFT and COMP showed number of measurements possible to be performed (six months). (Tables 2 and 3).

The other characters evaluated in this study showed measurements of high number, and over eight months of evaluation is necessary to confirm data authenticity with $80 \%$ certainty. The authors observed that for the most important character for commercialization and for being 
directly related to the size (average mass of marketable fruit), at least 20 evaluations are necessary to reach this determination.

In order to reach determination levels greater than $90 \%$, the characteristics should be evaluated twice in relation to determination of $80 \%$. There would be needed 12 evaluations for average mass of total fruits, 44 evaluations for average mass of marketable fruits, 14 for length, 17 for diameter, 47 for total production, 30 for commercial production, 91 for number of total fruits and 34 for number of marketable fruits (Table 3). The attempting to increase accuracy above $90 \%$ requires an increase in number of measurements in relation to accuracy gain, being useless besides making the process expensive and time consuming.

To conclude, fruit average mass and length obtained satisfactory number of measurements (six evaluations) to predict their real value, with determination coefficient of $80 \%$. All the characters showed estimates of repeatability and heritability coefficients with low to moderate magnitude, showing that no regularity in measurements of the characters of strawberry fruit production in the determined period was verified. Thus, low coefficient estimates showed the difficulties, which surely caused higher costs, concluding that superior or inferior perform of the cultivars may not be maintained. Thus, another method would be to improve the experimental conditions indicating the need for greater environmental control or increasing the number of repetitions so that selection could be carried out reliably.

\section{ACKNOWLEDGEMENTS}

The authors thank to Foundation for Research Support of Minas Gerais (FAPEMIG) and to the National Council for Scientific and Technological Development (CNPq) for the scholarships granted and financial support for this study. This project was supported by Coordination of Improvement of Higher Education Personnel (CAPES) Financing Code 001.

\section{REFERENCES}

ADEWALE, BD; ADEBO, UG. 2018. Phenotypic identity, similarity and stability for selection of tomatoes (Lycopersicon esculentum L.) cultivars in South-western Nigeria. Scientia Horticulturae 235: 264-269.

AZEVEDO, AM; ANDRADE JÚNIOR, VC; PEDROSA, CE; VALADARES, NR; ANDRADE, RF; SOUZA, JRS. 2016. Estudo da repetibilidade genética em clones de couve. Horticultura Brasileira 34: 54-58.

CARDOSO, AII. 2006. Número mínimo de colheitas em pepino híbrido estimado por meio do coeficiente de repetibilidade. Bragantia 65: 591-595.

CARGNIN, A. 2016. Repetibilidade e número de colheita de características para seleção de clones de variedades viníferas. Ciência. Rural 46: 221-226.

CRUZ, CD; REGAZZI, AJ; CARNEIRO, PCS. 2012. Modelos biométricos aplicados ao melhoramento genético. Viçosa: UFV, 514p.

GUIMARÃES, AG; ANDRADE JÚNIOR, VC; AZEVEDO, AM; GUEDES, TJ; PINTO, NAVD. 2016. Quality of strawberry grown in Brazilian tropical humid conditions for breeding programs. Fruits 71: 151-160.

GUIMARÃES, AG; ANDRADE JÚNIOR, VC; ELSAYED, AYAM; FERNANDES, JSC; FERREIRA, MAM. 2015. Potencial produtivo de cultivares de morangueiro. Revista Brasileira de Fruticultura 37: 112120.

GUIMARÃES, AG, OLIVEIRA, CM, VIEIRA, G, PINTO, NAVD. 2014. Qualidade físicas e químicas de morango passa em diferentes embalagens. Engenharia na Agricultura 22: 306-316.

HENZ, GP. 2010. Desafios enfrentados por agricultores familiares na produção de morango no Distrito Federal. Horticultura Brasileira 28: 260-265.

LIRA JÚNIOR, JS; BEZERRA, EF; MOURA, RJM; SANTOS, VF. 2014. Repetibilidade da produção, número e peso de fruto em cirigueleira (Spondias purpúrea L.). Revista Brasileira Fruticultura 36: 214-220.

LOPES, R; BRUCKNER, CH.; CRUZ, CD; LOPES, MTG; FREITAS, GB. 2001. Repetibilidade de características do fruto de aceroleira. Pesquisa Agropecuária Brasileira 36: 507-513.
MANFIO, CE; MOTOIKE, SY; SANTOS, CEM; PIMENTEL, LD; QUEIROZ, V; SATO, AY. 2011. Repetibilidade em características biométricas do fruto de macaúba. Ciência Rural 41: 70-76.

MISHRA, PK; RAM, RB; KUMAR, N.2015. Genetic variability, heritability, and genetic advance in strawberry (Fragaria $\times$ ananassa Duch.). Turkish Journal of Agriculture and Forestry 39: 451-458.

OLIVEIRA, MSP, FERNANDES, GLC. 2001. Repetibilidade de caracteres do cacho de açaizeiro nas condições de Belém-PA. Revista Brasileira Fruticultura 23: 613-616.

PIMENTA, S; MENEZES, D; NEDER, DG; MELO, RA; ARAÚJO, ALR; MARANHÃO, EAA. 2016. Adaptability and stability of pepper hybrids under conventional and organic production systems. Horticultura Brasileira 34: 168-174.

RESENDE, MD. 1995. Delineamento de experimentos de seleção para maximização da acurácia seletiva e do progresso genético. Revista Árvore 19: 479-500.

RESENDE, MD. 2006. Software Selegen-REML. BLUP. Manual. EMBRAPA. Campo Grande, Brasil. 73p.

RESENDE, MDV. 2002. Genética biométrica e estatística no melhoramento de plantas perenes. Brasília: Embrapa Informação Tecnológica. 975p.

RONQUE, ERV; VENTURA, MU; SOARES JÚNIOR, D; MACEDO, RB; CAMPOS, BRS. 2013. Viabilidade da cultura do morangueiro no Paraná-BR. Revista Brasileira Fruticultura 35: 1032-1041.

SALES, WS; ISHIKAWA, FH; SOUZA, EMC; NASCIMENTO, JHB; SOUZA ER; LEÃO, PCS. 2019. Estimates of repeatability for selection of genotypes of seedless table grapes for Brazilian semiarid regions. Scientia Horticulturae 245: 131-136.

SILVA, HC; ANUNCIAÇÃO FILHO, CJ; BASTOS, GQ; DUTRA FILHO, JA; SIMÕES NETO, DE. 2018. Repeatibility of agroindustrial characters in sugarcane in different harvest cycles. Revista Ciência Agronômica 49: 275-282.

SOUZA SOBRINHO, F; BORGES, V; LÉDO, FJS; KOPP, MM. 2010. Repetibilidade de características agronômicas e número de cortes necessários para seleção de Urochloa ruziziensis. Pesquisa Agropecuária Brasileira 45: 579-584.

VIEIRA, SD; SOUZA, DC; MARTINS, IA; RIBEIRO, GHMR; RESENDE, LV; FERRAZ, AKL; GALVÃO, AG; RESENDE, JTV. 2017. Selection of experimental strawberry (Fragaria $x$ ananassa) hybrids based on selection indices. Genetics and Molecular Research 16: 1-11. 